\title{
Severe Tophaceous Gout with Radiograph Examination of Diffused Calcified Soft Tissue Tophi
}

ERWAN OEHLER, MD, Department of Internal Medicine, Taaone Hospital, Pirae, Tahiti, French Polynesia; TRISTAN PASCART, MD, Department of Rheumatology, Saint-Philibert Hospital, Lille Catholic University, Lomme, France. Address correspondence to Dr. T. Pascart, Saint-Philibert Hospital, Rheumatology, rue du Grand But, Lomme, 59160, France. E-mail: pascart.tristan@ghicl.net. J Rheumatol 2015;42:1259-60; doi:10.3899/jrheum.150181

A 44-year-old man presented to our hospital with severe polyarticular familial gout. He experienced recurrent attacks on a monthly basis, and multiple tophaceous deformations appeared over the years as serum urate levels remained above $10 \mathrm{mg} / \mathrm{dl}$ in spite of a daily treatment by allopurinol $600 \mathrm{mg}$. This led to dramatic infirmity as demonstrated by the deformities because of tophi development (Figure 1), leaving him entirely dependent on his family for everyday care. The presented radiograph examination of the left foot demonstrated massive calcified soft tissue urate deposits and intrabone tophi (Figure 2). Parathormone, calcium, and phosphate levels were normal.

Prevalence of gout in Polynesia is high because of the combination of the adoption of occidental food diets and genetic predisposing factors, especially the mutation of renal urate transporter genes leading to decreased urate excretion $^{1,2}$. Tophaceous gout affects $15 \%$ to $20 \%$ of patients with gout ${ }^{3}$. Tophi are classically radio-transparent ${ }^{4}$, but such case illustrates the possibility of associated calcic crystals, especially in cases of renal impairment such as the one affecting our patient (estimated glomerular filtration rate 47 $\mathrm{ml} / \mathrm{min}$ ). These calcifications could be the result of a persistent inflammation taking place within tophi as proven by histological studies ${ }^{5}$. Severe cases of tophaceous gout are responsible for joint destruction and severe disability. Prolonged treatment by urate-lowering therapies can maintain serum uric acid levels below urate crystallization levels and eventually deplete urate deposits, which ultimately leads to tophi regression.

\section{REFERENCES}

1. Flynn TJ, Phipps-Green A, Hollis-Moffatt JE, Merriman ME, Topless R, Montgomery G, et al. Association analysis of the SLC22A11 (organic anion transporter 4) and SLC22A12 (urate transporter 1) urate transporter locus with gout in New Zealand

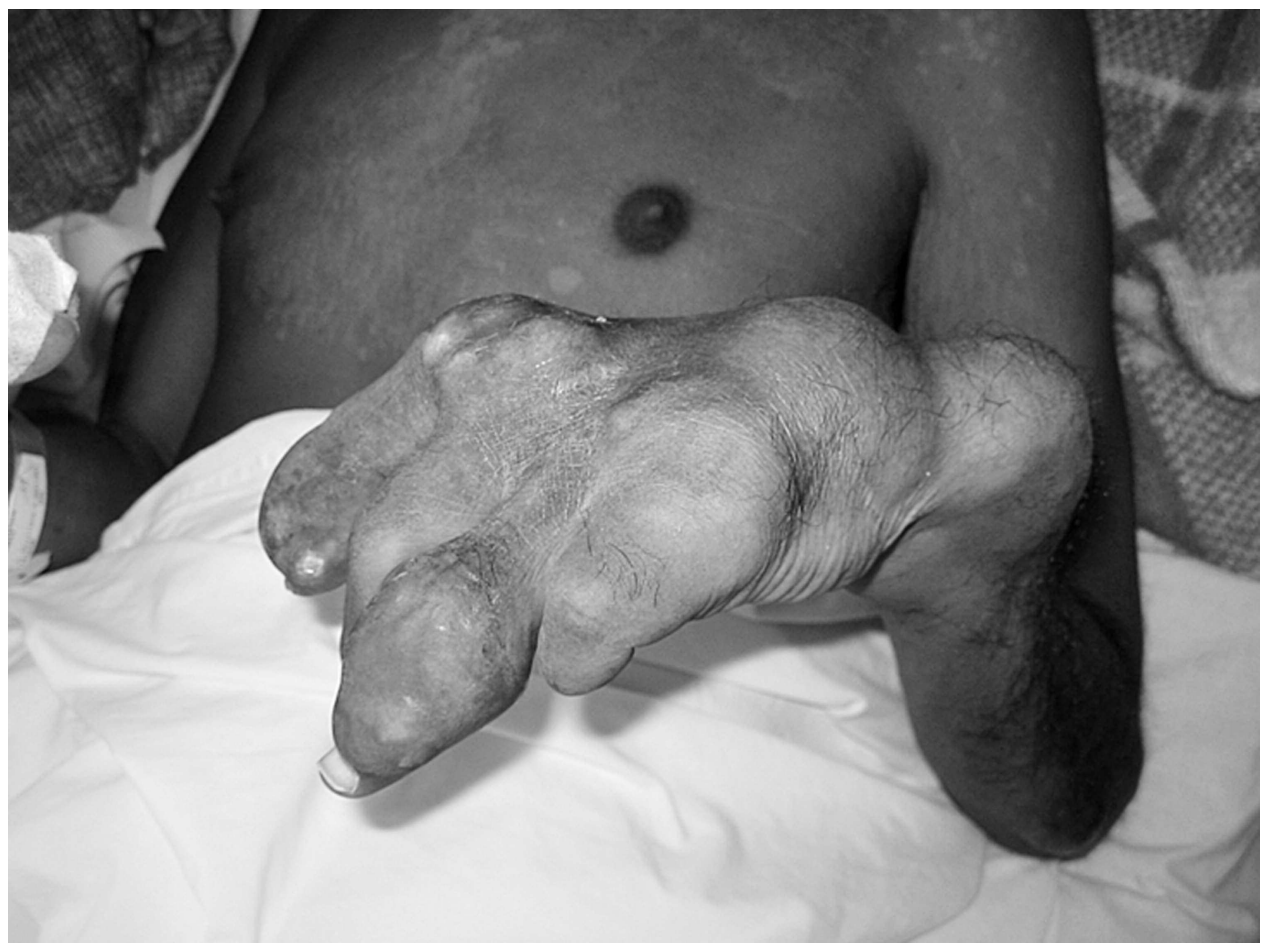

Figure 1. Tophaceous deformations of the left hand. 


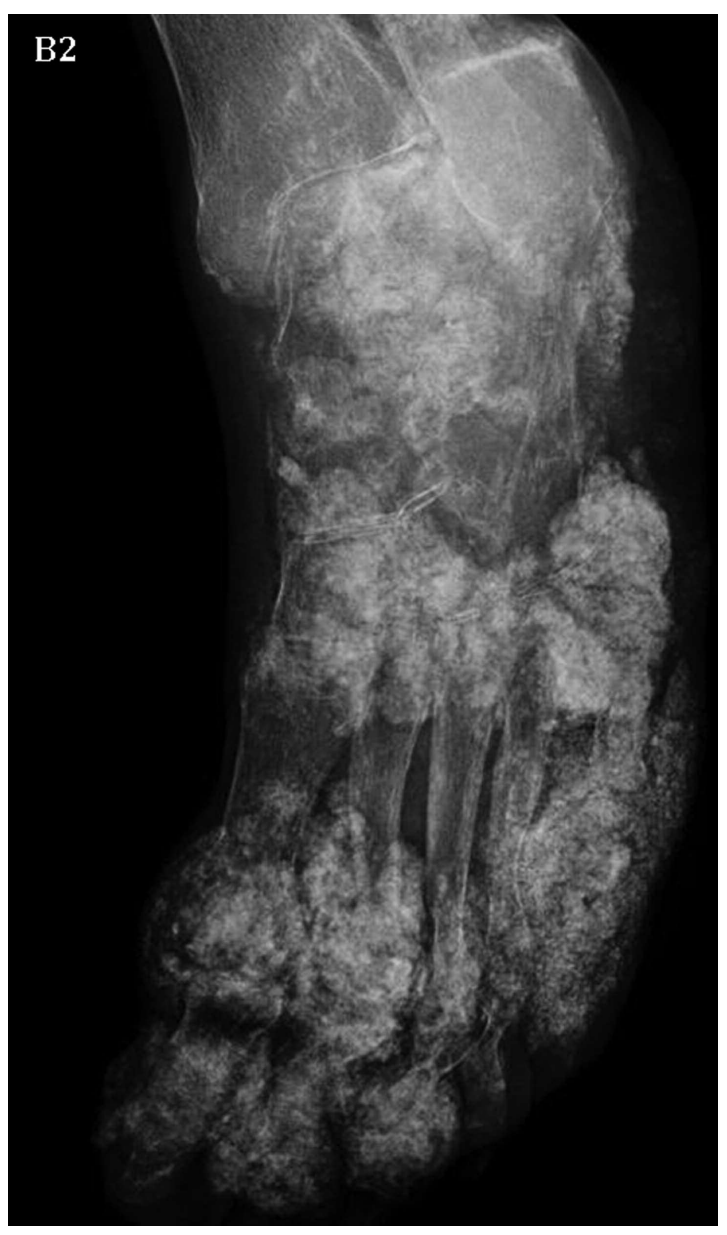

case-control sample sets reveals multiple ancestral-specific effects. Arthritis Res Ther 2013;15:R220.

2. Simmonds HA, McBride MB, Hatfield PJ, Graham R, McCaskey J, Jackson M. Polynesian women are also at risk for hyperuricaemia and gout because of a genetic defect in renal urate handling. $\mathrm{Br} \mathrm{J}$ Rheumatol 1994;33:932-7.

3. Dalbeth N, House ME, Horne A, Taylor WJ. Reduced creatinine clearance is associated with early development of subcutaneous tophi in people with gout. BMC Musculoskelet Disord 2013;14:363.

4. Gentili A. The advanced imaging of gouty tophi. Curr Rheumatol Rep 2006;8:231-5.

5. Dalbeth N, Pool B, Gamble GD, Smith T, Callon KE, McQueen FM, et al. Cellular characterization of the gouty tophus: a quantitative analysis. Arthritis Rheum 2010;62:1549-56.

Figure 2. Plain radiography of diffuse calcified tophi of the left foot. 